ARTICLE

Received 26 Sep 2016 | Accepted 7 Mar 2017 | Published 6 Apr 2017

\title{
A race towards credibility: the 2009 and 2013 presidential election campaigns at the Fédération Internationale de l'Automobile (FIA)
}

\author{
Hans Erik Næss ${ }^{1}$
}

\begin{abstract}
Fédération Internationale de l'Automobile (FIA), the governing body of world motorsports, is one of many Global Sport Governing Bodies (GSGBs) facing increasing demands for good governance. By inadequately complying with international guidelines on organizational conduct these organizations, which are independent and powerful actors in global society, have received criticism from a broad range of actors. However, compared with other GSGBs like the International Federation of Football Associations (FIFA) and the International Olympic Committee (IOC), the FIA is uncharted territory. Through a qualitative document analysis (QDA) of the FIA presidential election campaigns in 2009 and 2013 this article therefore aims to fill this gap by examining the candidates' struggle for credibility with stakeholders on the key principles of good governance: democratic representation, transparency and accountability. Drawing upon campaign material and articles in newspapers and in motoring magazines covering the elections, the analysis demonstrates that all FIA presidential candidates advocated a strong emphasis on these principles, but were vague as to how they should be put into practice. Moreover, the candidates' attempt to procure credibility for themselves and for the FIA by raising the issue of good governance seemingly gained them few votes. Of several possible reasons for this two can be highlighted: first, because the FIA membership had more faith in the winning candidate's ability to develop a stakeholdereffective FIA; second, because the FIA membership did not regard the credibility of the organization itself as being dependent on the adoption of good governance practices.
\end{abstract}

\footnotetext{
${ }^{1}$ Westerdals Oslo School of Arts, Communication and Technology, Oslo, Norway Correspondence: (e-mail: hans.erik.ness@westerdals.no)
} 


\section{Introduction}

édération Internationale de l'Automobile (FIA), the govern- ing body of world motorsports, is but one Global Sport Governing Bodies (GSGBs) facing increasing demands for good governance- "high standards of democratic representation, accountability and transparency" (Woods, 1999, p. 39; see also Houlihan, 2004; Geeraert et al., 2013). Established in France in 1904 as a club of wealthy "petrolheads", it has since become a major actor in the world of motoring and racing and, in 2017, has 245 member clubs in 143 countries. Especially due to the financial growth of Formula 1, the most prestigious of the championships it governs, it has acquired a financial reserve of some $€ 140$ million, ${ }^{1}$ which blurs the line between the FIA's official status as non-profit organization and facilitator for some of the world's most commercial enterprises. When this is taken into consideration along with the stir caused by other GSGBs who have failed to meet common ethical standards, such as IOC and FIFA (see Tomlinson, 2014; Hassan and Mitra, 2016), the time appears ripe for an investigation into how FIA addresses the principles of good governance.

One particular area where this question has become noticeable is the body's presidential elections, as the personal visions of the FIA president have traditionally had great influence on the development of the organization (Hutton, 2004; Lovell, 2004). As Max Mosley, FIA President from 1993 to 2008 (2015, 142, 190, 198) and others have recalled (see Lovell, 2004), central reforms in the organizations were the direct result of the FIA president's wishes. Drawing upon campaign material and articles from newspapers and motoring magazines, this article investigates the 2009 and 2013 election campaigns for the FIA presidency. While all candidates emphasized the importance of good governance, however, they differed on the operationalization of fairer democratic representation and on how to enhance transparency and accountability. The presidential challengers, who tried to make use of these principles on their own behalf, and for the good of FIA, assumed that this would resonate with FIA members. However, despite harsh criticism of the existing governance structure, the challenging candidates' efforts to raise FIA's credibility made little impression on FIA members, possibly because neither they, nor the current president appear to see the organization's credibility as dependent on operationalizing principles of good governance.

\section{Data and methods}

This article relies on QDA, which, according to Altheide (1996: 23-24), includes five steps: (a) finding and getting documents, (b) protocol development and data collection, (c) data coding and organization, (d) data analysis and (e) report. In reference to (a) and (b), this paper draws upon two sources which, while being different in kind, are similar in character: both are documents, "any symbolic representation that can be recorded and retrieved for description and analysis" (Altheide, 1996: 2), or more specifically "text (words) and images that have been recorded without a researcher's intervention" (Bowen, 2009: 27). The first kind of document is campaign election material. As the candidates had various degrees of public engagement, this material is gathered from official websites as well as secondary sources. The second kind of document is newspaper articles and motoring magazines covering the elections. These are included because most of the links to original sources, such as letters from FIA presidential candidates, are dead. Rather than commentaries and op-eds, special emphasis is laid on utterances by the presidential candidates. As a result, these documents can be seen as "social facts", which are produced, shared and used in socially organized ways (Atkinson and Coffey, 1997: 47).
In reference to c) and $\mathrm{d}$ ), the coding of content, that is, "excerpts, quotations, or entire passages" (Bowen, 2009: 28) from these documents, was organized into categories "related to the central questions of the research" (Bowen, 2009: 32). Altheide (1996: 8) argues that coding should reflect the idea that "social life consists of a process of communication and interpretation regarding the definition". Moreover, process, or how something is put together, must be paired with context, "or the social situations surrounding the document in question, must be understood to grasp the significance of the document itself" (1996, p. 9, italics original). For that reason, a historical contextualization is provided before we turn to how the presidential candidates' views on good governance are coded according to two dimensions-developmental (how they reflected upon good governance principles) and operational (suggestions on how these principles might be implemented) that shaped the election debates. The approach is characterized by the researcher exploring the meanings attached to specific concepts rather than taking a holistic approach (Wesley, 2014: 151). This choice, it is argued, provides a rich display of the presidential candidates' views on matters of good governance as well as on each other and the context of the debate. The coding of the documents was, therefore, performed as a way of grasping the totality of the presidential candidates' views rather than making technically perfect classifications.

At last, concerning e) and $\mathrm{f}$ ), the analysis is inspired by the technique within QDA of "tracking discourse", that is, "following certain issues, words, themes, and frames over a period of time, across different issues, and across different news media" (Altheide et al., 2008: 130). Although QDA is not primarily suited for "widespread generalizations" (Altheide et al. 2008: 149), this article resembles other studies of GSGBs as the increasing involvement in business and politics has put their traditional independence under pressure (Mosley, 2015; Economist, 2011; Geeraert et al., 2013). The meaning of concepts associated with "good governance" therefore has to be analysed in light of their use and content elsewhere. Consequently, because of FIA's structure as a member organization, it is argued that the debates above all revealed a struggle for credibility - a multidimensional concept comprising "the perceiver's assessment of the communicator's relevant knowledge, veracity, and good intentions toward the perceiver" (Simons, 2002: 22). According to Du Plessis (2005: 65) it is also relevant to acknowledge how credibility is time-sensitive "because nowadays, the organization's perceived credibility may differ completely from its perceived credibility by the same organization in future". On one hand, it was used as means-something the candidates could use to develop FIA's policy. On the other hand, it was seen as an end, to which the candidates' policies-and the corresponding support among FIA member clubs-would lead them.

The calibre of qualitative research can be gauged by whether or not one achieves a specific kind of analytic credibility, that is, "reports ... that readers feel trustworthy enough to act on and make decisions in line with" (Tracy, 2010: 843). This highlights potential weaknesses of QDA: the documents may have insufficient detail or be selected according to a bias, or they may be used as a stand-in for other kinds of evidence (Bowen, 2009: 32-38; Wesley, 2014: 152). In this article, an attempt is made to answer the first criticism, most notably in the form of sampling, by searching for documents that cover the phenomena as completely as possible, not only those that support the initial research argument (Potter, 2009: 287). An account of the links between the methodological framework with the documents, the factual elements of the presidential elections, and the analysis (cf. Tracy, 2010: 848) makes this explicit. With regard to the possible 
use of documents as a stand-in, interviews with the candidates and their campaign teams might have provided an additional method. This would have generated insights about election tactics and the candidates' motivation for running. On the other hand, these insights would have affected the analysis as the interviewees all have a position to advocate (Clark, 2010: 400). It was therefore decided to restrict analysis to the campaign itself, and the debates between the candidates, rather than the campaign camps' views on it afterwards.

\section{Historical context}

Good governance first became a topic in the international community after the Second World War. While at first it denoted structural reform in and between states in order to achieve democracy and economic growth, it gradually turned into "the establishment and operation of ... the rules of the game that serve to define social practices, assign roles, and guide interactions" (Young, 1994: 15). This broader understanding of the concept, according to Woods (1999: 40), involved political and sociological research "on the conditions and institutions needed to represent and mediate the vast and competing array of interests in any society" (see also Hood, 2006). Among these interests, we find actors like FIFA, FIA and IOC who have all developed to the point where they produce a particular kind of social impact (Geeraert et al., 2013). FIA, however, was at first most concerned about the world's impact on it. Sometime in the mid-1960s, FIA Presidents Willifred Andrews (1965-1971) and Prince Amaury de Merode (1971-1975) agreed that reforms were needed.

According to Hutton (2004: 111), an ad hoc committee was set up in 1971 to review FIA's structure. At that point, it included 86 clubs from 76 countries, had an annual budget of 1.5 million francs, and derived about one-third of its income from motorsport. The committee found that "a complete redesign of the FIA's sports administration was required and that the Federation should benefit more financially from it" (Hutton, 2004: 111). The report also stated: "Sport is the FIA's unique feature-its rights as an international controlling body are never questioned-and there is the opportunity for the FIA to get a fair share from the commercial side of the sport" (cited from Hutton, 2004: 111). Despite this recommendation, FIA President from 1975-1986, Prince Paul Metternich, was more an ambassador for FIA than someone who dealt with the nuts and bolts of the organization (Hutton, 2004: 214). In the meantime, Jean-Marie Balestre became chairman of Commission Sportive Internationale de la FIA (CSI), an autonomous satellite body created back in 1922 by what would become FIA to oversee motorsport activities. By renaming CSI in 1978 as Fédération Internationale du Sport Automobile (FISA), Balestre began to transform the rest of the organization from within: "He took his vision of the future to the delegates from clubs around the world to enlist their support. Never before had the FIA seen this kind of electioneering" (Hutton, 2004: 215).

Also during this period, the so-called FISA-FOCA war was taking place. Named after the conflict between FISA and the Formula One Constructors Association (FOCA), it came about because Formula 1 team owners and commercial entrepreneurs had criticized both the way Formula 1 was run and the disbursement of the proceeds. As a result, they formed FOCA with Bernie Ecclestone as its key figure and FOCA leader in 1968 as a means to influence matters at FIA. Balestre saw this is as an inappropriate interference with his work and, according to Hamilton (2009) "he had every intention of returning it [Formula 1] to its rightful place within the FIA headquarters in Place de la Concorde". Contrary to FIA's 1971 recommendation, Ecclestone and his ally Max Mosley argued that a separation of commercial and governing responsibilities would benefit both the FIA and FOCA, as well as complying with EU regulations (Mosley, 2015: 164-67).

After a brief period during which FOCA threatened to create its own world championship and a continuous war of words, Balestre and Ecclestone realised that a compromise had to be made and this was reached in January 1981. This resulted in the Concorde agreement, in essence a contract between the FIA, the FOCA (which has subsequently appeared in a number of constellations) and the teams on the rules of participation in, and the distribution of revenue from, Formula 1. Once Balestre was appointed Deputy President at FIA in 1981, and with the Concorde agreement in hand, there was nothing stopping himthere were no other candidates-from succeeding Metternich in 1985. His uncompromising leadership style, however, proved unsustainable (Cotton, 1991). When Group B of the FIA World Rally Championship was hastily banned by Balestre personally for safety reasons and the agreed alternative was scrapped as well, team manager of Peugeot Talbot's World Rally Team at that time -and later FIA President-Jean Todt described him as the "Napoleon of the sands". 2

He was succeeded by Max Mosley, but even before his presidency began there were new upheavals in the relationship between FISA and FOCA. Mosley was in fact one of the leading forces behind FOCA and he had succeeded Balestre as FISA president in 1986. Two years later, Balestre's chief opponent in the FISA-FOCA war, Bernie Ecclestone, was appointed FIA VicePresident (responsible for Promotional Affairs). Besides having close ties with Ecclestone, Mosley, a qualified barrister, won the 1993 FIA presidential election first and foremost because he used the entire toolbox of political campaigning to gain support (Saward, 1993). At that time, the voting procedures were already a cause for concern because they favoured the incumbent (Mosley, 2015: 195-196). Moreover, as FISA was seen by Mosley as a threat to how FIA governed Formula 1 and other world championships, he and Ecclestone suggested (see Mosley, 2015: 198) that the two FIA bodies should be merged and FIA reorganized. While Balestre was given the important new post of President of the FIA Senate, and FISA abolished, Mosley and his vice-President Ecclestone acquired complete control of both governing and sporting aspects of FIA's portfolio of world championships.

This power alliance, however, brought with it some challenges to FIA's governance structure. Because FIA promises to "establish a union between its Members", 3 from whose annual subscriptions it derives much of its income, it is vital to deliver a sense of fair ownership among its stakeholders (Woods, 1999: 40). Mostly, this is done through voter arrangements and representative bodies. Accountability requires "clarity about whom or on whose behalf the institution is making and implementing decisions" as well as clarity about who has the power to limit or sanction the institution's work (Woods, 1999: 40). Transparency generally indicates an open flow of information-usually about finances, procedures and decisions-to those affected by how the organization uses this information and may generate trust among stakeholders (Holzner and Holzner, 2006). Without sufficient information and a structure that distributes responsibility within the FIA, the stakeholders-most notably FIA members-cannot exercise their democratic rights. What is more, those stakeholders outside the political channels of FIA are dependent on an informed dialogue with those heading FIA bodies on behalf of others where access to information is otherwise limited.

Before the presidential campaigns in 2009 and 2013, these issues surfaced several times. In 2001, both Ari Vatanen (who ran for FIA presidency in 2009, see below) and Mosley were speakers 
at the conference called "The Rules of the Game". At a session entitled "Principles of Good Governance" Mosley underlined: "Ultimately we must answer the question of whether it is all right to supervise yourself if you are democratic. Then again we must answer another question: what do we mean by democratic?" (Mosley, 2001: 24). He then answers by discussing the role of FIA's external stakeholders and make no mention of FIA's internal voting systems. But one hint of his understanding of democracy is the nomination system introduced by Mosley in 2005, which despite his professed concerns in the early 1990s, gives rise to a suspicion of "corporate inbreeding" (Bohlander and Schnell, 2010: 193). In this system, each candidate must put forward a 22-strong cabinet list of FIA members (raised to 37 before the 2013 election) with their application. No candidate can stand on more than one presidential list. This means that the candidate favoured by the current President or by current FIA members will find it easier to get the support of the most influential of FIA's 238 members-even before the election campaign. The outsider, on the other hand, will have to accept support from other members who are less influential (Cary, 2009a). ${ }^{4}$

Hence, at FIA, democratic representation, accountability and transparency are linked. In what follows, these three principles of good governance and the linkage between them are the centrepiece of the analysis of the presidential elections of 2009 and 2013. First, though, the run-up to the 2009 election demands a brief introduction. Before Mosley decided whether he would take on a fifth term as FIA president, former rally driver and Member of the European Parliament Ari Vatanen announced in July 2009 that he would challenge Mosley, should he not withdraw from his position. At first, Mosley denied he would run for another term, but backed by FOTA (an offspring of FOCA), he reviewed the matter while Vatanen went public with the reasons for his candidacy. In his campaign statement, entitled "Transparency to the FIA", he says: "My main focus will be to bring unity to the FIA and increase transparency and accountability for the members, who are after all the true owners of the Federation and must play a central role in our organization." ${ }^{5}$ The next day, Vatanen emphasized his worries about FIA's electoral system: "Obviously it favours the incumbent, but I've nothing to lose" (cited in Cary, 2009a).

\section{The developmental dimension: the 2009 and 2013 elections}

Vatanen's scepticism about the current system was not coincidental. Six days after he announced his candidacy, on 16 July 2009, Jean Todt officially announced his intention of running for the Presidency of FIA. The day before, Todt had received the support of outgoing President Max Mosley, who had decided not to stand for re-election. Mosley also highlighted the FIA road safety and environmental campaigns both Todt and his partner, Hollywood actress Michelle Yeoh, had been involved in. It did not take long for Vatanen publicly to express his indignation about Mosley's-arguably an influential man in FIA circles-support for Todt's candidacy before the real campaigning had begun: "It's not right that Max wants to impose a new leader, and that he uses the power of the federation to support his campaign. The FIA is not a kingdom; it's a republic where the leaders are chosen democratically" (cited from Noble and Elizalde, 2009).

Elsewhere, Vatanen stated that it was unfair that Todt, a trustee of the FIA Foundation (an independent charity established with financial funds from FIA and registered in the United Kingdom), campaigned at the Foundation's expense during his voluntary work. Worse, he did it alongside his wife Michelle Yeoh, a global ambassador of the Foundation's "Make Roads Safe" campaign
(Cary, 2009b). The Chairman of the FIA Foundation, Carlos Macaya, refuted Vatanen's claim, saying:

These activities have nothing whatsoever to do with the FIA, or the recently announced election. It is very disappointing that you have chosen to misrepresent the work of a fellow Trustee in this way and belittle the magnificent contribution being made by Michelle Yeoh (cited from Panzariu, 2009a)

Finally, Jean Todt, who had up to this point made no statement about the matter, issued a response on 22 July urging "all candidates" (as if there were any other candidate than Vatanen) to "conduct their campaigns with dignity" and adding: "In future I hope everyone can stick to the issues and respect the integrity of this democratic process". 6 Unfortunately for Todt, Vatanen's cause gained momentum when British newspaper The Daily Telegraph quoted leaked e-mails from David Ward, the Director General of the FIA Foundation, in which he discussed strategies for lobbying in Todt's favour and edits of Todt's policy documents. Ward defended himself by stating that his work for Todt had no connection to the Foundation and was a private initiative (Beer, 2009). However, the majority of those e-mails were sent from FIA Foundation e-mail addresses, as well as from the chair of FIA's Motor Sport Safety Development fund which disburses large amounts of money on behalf of the FIA (Cary, 2009c), which calls into even greater question the FIA's impartiality in the election process. While there is nothing in FIA's statutes that forbids lobbying, these forms of persuasion could constitute a breach of French law, under which FIA is governed, specifically the principle of neutrality (Panzariu, 2009b; Cary, 2009c).

Despite this turmoil, Todt remained absent from public debate and concentrated instead on campaigning among FIA member clubs, until he released his presidential manifesto on 6 August: "Over the next four years, the FIA should seek to build on its strengths, but also be ready to adapt its management and decision-making structures to make them more cost-effective, responsive and transparent ... We propose a thorough review of the FIA statutes to adapt and modernize where necessary the Federation's structure and rules". 7 Shortly after, Vatanen released his presidential manifesto on 20 August, in which he noted that:

All major organizations are subject to increased scrutiny and therefore we also have to establish a real corporate governance to deal with potential conflicts of interest and to have transparency for the member clubs. The hallmarks of my team are values, honesty and transparency (Vatanen, 2009).

Two days later, it was revealed that Mosley had circulated a letter in which he warned that, "those who vote for Vatanen in next month's election, can expect to be marginalized under Jean Todt." 8 This was interesting news as, when Mosley stood for election in 1991, he had said that: "Typical of what I am trying to say is that the reason no one has stood against Jean-Marie Balestre [the then President] until now is not that everyone agrees with him, that there's no one there who thinks they could do the job better. It's because they fear that the consequences could be adverse" (cited from Saward, 2008). While Vatanen threatened legal action, Todt refrained from public debate until, on 14 October, he made the following comment: "We would appeal to all FIA member clubs to concentrate on the real issues ... and we hope that the personal attacks and false allegations will stop". 9

This did not prevent Vatanen from producing a new letter that was delivered by a huissier de justice (a public official) to FIA's 
headquarters in Paris on 15 October, in which he accused Mosley of breaching the above-mentioned "principle of neutrality". Actually, Vatanen applied to the Tribunal de Grande Instance de Paris (the court which has jurisdiction over civil matters in France) in a bid to ensure the forthcoming election should be "fair and transparent" (Gibson, 2009). FIA responded with a statement that the current system already "provide[s] more safeguards than those he is asking the court to impose" (Gibson, 2009). The next day, the two parties met at FIA's headquarters in Paris. Because of the campaign advantages that Vatanen accused the Todt camp of having-campaigning at the FIA's expense and getting access to clubs that Vatanen did not have, thus creating an "information asymmetry" which breached the principle of transparency (Hood, 2006: 17)), the key issue was to ensure that the ballot papers were distributed at random so that votes could not be traced to individual member organizations. Though the FIA had at first insisted that "the envelopes in which the ballot papers would be enclosed would be unmarked and indistinguishable", in the event, Vatanen was given the right to have the elections supervised by a huissier de justice throughout and there was a private voting area for marking ballot papers (Gibson, 2009). A week later, on 23 October 23, Todt defeated Vatanen by 135 votes to $49 .^{10}$

While Todt and Vatanen eventually teamed up some time after the election, when Todt created the rally safety commission which was headed by Vatanen, the next presidential election four years later would demonstrate a new level of attention to good governance. David Ward, former head of the FIA Foundation and one of Todt's lobbying allies in 2009 (see above), released his "Agenda for Change" on 5 September 2013 in which he announced his candidacy. The election was due on 6 December 2013. On the website wardandteam2013.com (now defunct), he applauded the work done by Mosley and Todt in reforming the FIA, but also underlined that:

The FIA can give the impression of being antiquated and autocratic. The powers of the Presidency are too wide to be effective or fully accountable. In some areas the trend for reform has been reversed. For example, the maximum possible period in office for the President has been extended from eight years to twelve. The threshold for nominations for Presidential candidates has been set high which favours the incumbent and deters other candidates. ${ }^{11}$

As if to confirm his engagement with these issues, he later commented: "All I would ask is for a fair hearing for the governance reforms that I believe are necessary to strengthen the effectiveness, transparency, and accountability of the FIA so that it can better serve the interests of its membership" (cited from Cooper, 2013a). The next day, on 6 September, Ward filed a complaint to FIA Ethics Committee alleging that Todt had used "FIA resources to try to predetermine the election outcome", which he believed constituted, "a serious violation of the FIA's rules, regulations and ethical code" (cited from Cary, 2013a). Todt rejected any suggestion of unethical behaviour and said about the support from the clubs: "How can I avoid it? If you have a group of people who say 'You are doing a good job. We want you'. I never put a knife, or a gun to someone's head" (cited from Cary, 2013b).

On 22 October, Ward-as well as all the FIA's member clubsreceived a report from the Committee, which concluded that nothing it saw or heard "gives any hint that any ethical regulation of the FIA has been breached by Mr Todt or any of the parties implicated". In addition, the Committee criticized Ward for bringing this up in the midst of an election campaign: "As put forward by Mr Ward himself, he has been serving the FIA for 20 years and knows the legal framework very well. It is, therefore, inappropriate for such an experienced executive, particularly for someone who is currently running for the FIA presidential election, to challenge the regulations before the Ethics Committee in the heat of the election" (cited from Cary, 2013b). Ward, however, commented as follows on the Committee decision: "Interestingly, the IOC Ethics Committee has nine members, five of whom are nothing to do with IOC member associations. But in the FIA's Ethics Committee, they are all senior office holders of the member clubs. That is the flaw" (cited from McEvoy, 2013).

Notwithstanding these accusations, Todt concentrated on promoting his own re-election campaign under the heading "The Road Forward-2013-2017". On the official website, we can read that Todt is proud of having established the Statutes Review Commission "to thoroughly examine how the FIA operates". ${ }^{12} \mathrm{He}$ goes on to say that these changes, which according to the progress report were unanimously supported at two General Assemblies, ${ }^{13}$ included reform of the electoral process, the handing of broader responsibilities to the FIA Senate and the establishment of the FIA's first-ever independent Ethics Committee. ${ }^{14}$ Moreover, he states that, "the constructive changes introduced also saw FIA member clubs become fundamentally involved in decision-making at the highest level". ${ }^{15}$

The role of the President in Todt's campaign is left untouched. Ward, by contrast, as one of 20 detailed suggestions on how to improve FIA's governance, specifically aimed at reforming the President's status: "The FIA President would have the possibility to serve in a non-executive role. The appointment of a Chief Executive Officer and the creation of a Management Board would give the FIA a new professional strategic capacity it currently lacks" (cited from Cooper, 2013b). One reason, apparently, for going after the President was the revision of the electoral ruleintroduced sometime during Todt's first period-whereby a candidate now had to submit a list and support nominations from 37 FIA member clubs, compared with 22 in the 2009 election. According to Ward, "This is excessive and increases the democratic deficit in the FIA's election system" (cited from Cooper, 2013b).

Although it did not change the system as much as Ward desired, FIA at least issued a clarification of the selection of these cabinet members as well as lowering the number to 11 . Ward, however, claimed this was a "huge embarrassment" to the FIA and, in his view, it confirmed his argument that the existing system was not fit for these kind of electoral processes (Osborne, 2013). Eventually, Ward found it impossible to secure the required number of clubs and withdrew from the election on 13 November. In a letter announcing his decision, he states that while his intention was "to promote transparency, accountability and democracy in the FIA", this democratic flaw in the electoral system made it very difficult to pursue that aim (cited from Cooper, 2013c). Consequently, Todt won the election unopposed.

\section{The operational dimension: implementing good governance}

So, in the Presidential elections of 2009 and 2013, we've seen that all three candidates embraced the established principles of good governance-democratic representation, accountability and transparency-and emphasized them as qualities their presidency would promote. This raises two critical questions: first, as Woods objected: "if international organizations are going to become more participatory, accountable, and transparent, what standards are relevant to them?" (Woods, 1999: 44). Second, how detailed was the communication of the issues related to operationalizing these principles? Regarding the first question, an obvious point of reference for FIA would be the IOC's standards or those applied 
by FIFA, but no mention of other sporting bodies was discovered in the 2009 election. Although it might have been mentioned in other documents not included in this article, in the material perused, there was no reference to established principles, agreements or other sporting bodies facing the same issue. What is more, whether the Todt campaign was guilty of breaching the principle of neutrality or not, was not addressed. In other words, the relationship between FIA's internal rules and French law was not seen as an issue by the candidates-and still is not-despite the fact that campaigning tactics were a matter of debate even in 2013.

Approaching the issue of comparable standards, Vatanen said on 17 October, 2009, that he wanted to introduce a Code of Ethics: "Such codes of behavior are the norm in the modern world of public life and business, where the need for ethical standards and transparent work practices are the key to public confidence" ${ }^{16}$ The substance of this Code of Ethics, however, was not set out in the documents and Todt did not reply with alternative reference standards. In 2013, Ward put this topic on the agenda, and operationalized it in his presidential manifesto:

Publish annual accounts that conform to International Accounting Standards and include a narrative from the President and CEO explaining the overall performance of the FIA, key developments of the year, any relevant issues or related party transactions and future plans ${ }^{17}$

Furthermore, in his withdrawal letter, issued when he pulled out of the election, Ward referred to other practices of good governance:

Last week the new President of the International Olympic Committee Thomas Bach speaking in the UN General Assembly said that sports organizations need to justify their autonomy and demonstrate good governance. He explained that the IOC's Universal Principles of Good Governance of the Olympic Movement should be accepted as a minimum standard at all levels of sport. I fully agree with President Bach and urge the FIA membership to study the Universal Principles carefully and use them to guide further reform to improve the FIA's transparency, accountability and democracy (cited from Cooper, 2013c).

Although researchers have several times questioned whether the IOC can be held up as the yardstick of good governance in GSGBs (MacAloona, 2011; EJC, 2013; Hassan and Mitra, 2016), Todt nevertheless countered Ward's claim by stating in 2013 that "the FIA now has a governance structure acknowledged to be best practice. This has been confirmed by the federation gaining full membership of the International Olympic Committee (IOC) and of SportAccord." 18 A report from the I Trust Foundation, commissioned by Ward and released on 2 December 2013, however, came to a different conclusion by using an assessment tool known as Basic Indicators for Better Governance in Sports Organizations (BIBGIS). While the report acknowledged that FIA recorded "12 maximum scores out of 63 governance indicators" (Rowland, 2013: 2), it also emphasized low scores ( 0 out of 4 ) with regard to stakeholder representation in the electoral system and in the level of transparency on financial reporting (Rowland, 2013: 5). All in all, FIA scored significantly lower than FIFA and the IOC. Then, following his re-election and without reference to this report, Todt criticized Ward on 10 December in the following terms:

I deeply regret that in the course of these last few weeks we have had unfounded insinuations cast on the FIA's governance, the transparency of its accounts, and the integrity of its members ... Faced with this irresponsible attack, we took a decision not to engage in a public fight with the media which would have only been destructive for our organisation. Instead we chose to address our clubs directly with the truth (cited from Cary, 2013b).

This claim about sitting on the truth brings me to the second critical question: how detailed were the candidates in outlining the principles of good governance: democratic representation, transparency and accountability?

Of the three candidates, Ward communicated the most detailed suggestions on how to improve FIA's transparency and accountability. Apart from the idea of converting the FIA Senate into a Supervisory Board (following modern corporate practice of a two tier board structure), Ward claimed that FIA should create a Management Board (with representation from each World Council and chaired by the FIA President) "responsible for budget matters, contract and due diligence supervision". Todt, for his part, pointed to the establishment of the Statutes Review Commission in 2009 which, 4 years later, was emphasized by his team as an important step in improving FIA: "The work of this independent commission, comprised of representatives from clubs around the world, has resulted in positive changes to the governance and administrative structure of the FIA".

In 2009, Vatanen had stressed changes in the electoral system as a way to achieve accountability and transparency. This brings us to the topic of democratic representation. Vatanen claimed that: "Todt is tied to people who have been in power for many years like Mosley and Ecclestone" (cited from Blitz and Allen, 2009).

Close ties need not be unethical if the general election process is up to standard with regard to "information disclosure". This concept "refers to the right of the public and the stakeholders of an organization to obtain important information relating to its financial matters, activities, and decisions" (EJC, 2013: 108). Nothing in the documents, however, indicates that the potential "inbreeding" was balanced by strategic actions to avoid information disclosure in either 2009 or 2013. This is underlined by Ward in his "Agenda for Change" in which he wishes to "ban any preelection period support letters" and suggests changes in the nomination process where Vice-Presidents of Sport were cut from the presidential list and the number of club nominations reduced to seven. According to Ward, "this would encourage multiple candidates to stand and restore fairness to the FIA election system" (cited from Cooper, 2013c). ${ }^{19}$ The current information asymmetry, he argued, potentially undermines the principle of accountability, as it "requires practical means that enable the stakeholders to monitor the organization's actions and evaluate them in this light" (Brown and Moore, 2001: 570-571).

Under point 4 in his 2009 manifesto, Vatanen therefore suggested: "One of the first steps is to appoint a small working group of respected FIA leaders both from Mobility and Motor Sport to review the structure and operations of the FIA" (Vatanen, 2009). In particular, he questioned FIA's one-seat, one-vote policy because, as has emerged from the workings of other GSGBs, it enables vote buying (Mittag and Putzmann, 2013: 84). Vatanen's (2009) aim, accordingly, was to "give the clubs a much stronger voice in the decisions we make at the FIA". Although he mentions reorganizing the electoral process, he does not go into detail. Todt in 2009, on the other hand, responded by saying that this rethinking of proportional representation would reverse, rather than promote, democratization:

The other declared candidate in the current election has proposed to change the voting system in the FIA to give more votes to larger clubs. We strongly disagree with this proposal which would simply concentrate power in the FIA among a small number of mobility clubs that have large 
individual memberships simply because they exist in countries with large populations. In fact some of our most successful clubs in both sport and mobility come from small countries and per capita have achieved very high membership levels. Why should they receive fewer votes just because geography limits the absolute size of their potential membership? We think it would be both unfair and undemocratic to move away from a system that gives all countries the same voting rights (cited from Skid, 2009).

Research, however, supports Vatanen on this issue. In their study of democratic representation in 13 transnational sporting organizations, Mittag and Putzmann (2013) found that all systems produce a conflict between egalitarianism and power. As an alternative, they write: "Transferring the approach of weighting of votes to international sport organizations may improve their democratic quality as well as reducing such dark sides as corruption and vote buying" (Mittag and Putzmann, 2013: 91). Moreover, the weighting of votes is but one part of a larger system, which should also incorporate double majority (voting by count and account) and participation in executive committees (Mittag and Putzmann, 2013: 92-93). This alternative system was, however, not discussed at the election debates.

\section{Analysis: a struggle for credibility}

As qualitative document analysis "entails a process of interpretation that emerges in interactions with the material (data)" (Altheide et al. 2008: 137), the discussion so far has been a dynamic where coding and interpretation have been two sides of the same coin, searching for patterns in data (Neuman, 1997: 426). Once a pattern is identified, Kohlbacher (2005) argues, "it is interpreted in terms of a social theory or the setting in which it occurred and that the qualitative researcher moves from the description of a historical event or social setting to a more general interpretation of its meaning". I have considered the historical contextualization and process dimensions of FIA's presidential elections in 2009 and 2013 from the perspective of credibility. Although these elections could also have been analysed from the perspective of "legitimacy" (Minikin, 2015), for example based on an examination of the voter system, I chose "credibility" because it embraces in a more comprehensive fashion many of the processes related to good governance that characterized the presidential debates. Altheide et al (2008: 149) also note that "the most important cultural and symbolic meanings for audiences and decision makers are not likely to be the most frequently occurring". Even though credibility never surfaced explicitly as an area of contestation in the FIA presidential elections, nor seems to have mattered much in the history of FIA, the interpretative analysis produced three reasons why it is a pivotal concept if we are to understand the content of the debates.

First, as suggested by studies of environmental debates, the amount of credibility is dependent on whether or not "the credibility of actors in a given domain requires them to draw on the ideas, concepts, and categories of a given discourse" (Hajer, 1995: 60). Similarly, the discourse of "good governance" in sport includes a far broader array of actors than FIA's inner circles, especially as GSGBs become increasingly involved in media, politics and business. A study of good governance in European professional football, for example, reveals that the identification of appropriate partners for instigating "social dialogue" (focusing on labour conditions) is not necessarily the same as locating stakeholders (Colucci and Geeraert, 2013: 6). They go on: "Social dialogue ... is essentially about the credibility of the sports stakeholders and their capacity to self-regulate their activities in the name of the autonomy that they claim" (Colucci and
Geeraert, 2013: 31). In their study of "co-opetition" as a possible management strategy in football, Lardo et al. (2016) conclude that no governing body of football can ignore the relational multitude of interests that create value. In other words, the credibility, actual or claimed, of the presidential candidates is no longer only a matter of what FIA members or the motorsport media think. That said, as demonstrated above, there are still question marks over the voting system, the extent of acceptable lobbying and the relationship between FIA's internal statutes and French law. At the time of writing, a few months before the election campaigns for FIA president 2017-2021 begins, there are no signs of change on this topic.

Second, partly because of the historical role of the president in the FIA, the credibility of FIA presidency was directly related to the candidates' personal visions for the FIA, and the candidate's negotiations with the various member clubs. Simons (2002: 1920) contends that behavioural integrity is a significant part of credibility, or more specifically, "a perceiver's assessment of believability, or of whether a given speaker is likely to provide messages that will be reliable guides to belief and behaviour". Leroy et al. (2012: 260) demonstrated "that authentic leadership is related to follower affective organizational commitment, fully mediated through perceptions of leader behavioral integrity". To some extent, FIA presidential candidates' self-image mirrors Weber's notion of charisma as source of authority, "a certain quality of an individual person by virtue of which he is considered extraordinary" (Weber, 1968 [1922], p. 241). Regardless of the candidate, this quality can be linked to the path-goal theory of leadership, which is concerned with understanding how "the influence of the leader's behaviour on subordinate satisfaction and effort is contingent on situational variables such as the nature of the task being undertaken and the characteristics of the subordinates" (Slack and Parent, 2006: 298). According to Yukl (1998: 266), these contingency variables "determine both the potential for increased subordinate motivation and the manner in which the leader must act to improve motivation" (cited in Slack and Parent, 2006: 298). In my view, the documents indicate that Todt focuses on "participative leadership", which, hypothetically, improve subordinates understanding of the relationship between their efforts and goal attainment increases; "it helps them select goals in which they are personally interested and hence toward which they are more likely to be motivated" (Slack and Parent, 2006: 298). Vatanen and Ward, on the other hand, seem to utilize "achievement leadership" which, on the basis of an unstructured start, approaches subordinates with ideas that "cause them to strive for higher standards of performance and to have more confidence in their ability to meet challenging goals" (House and Mitchell, 1974, 91; cited in Slack and Parent, 2006: 299). Knowing the history of FIA, it seems like Todt saw best how to use his leadership strategy to exploit its organizational contingencies to win the elections.

Third, credibility can be seen as a property of the GSGB as much as of the people running it. Herbig and Milewicz (1995: 7) argue that credibility is the "believability of an organization's intentions at a particular moment in time". In other words: "The more believable the message source, the more likely it is to influence the receptor" (Du Plessis, 2005: 65). Both Todt and Ward referred to the IOC in terms of best practice-examples of good governance, and in 2015, as part of the 2020 Olympic Agenda, IOC president Thomas Bach urged sporting bodies to embrace good governance to safeguard the credibility of sport: "In the long run, you cannot disassociate the credibility of sports organizations and the credibility of sports competitions." 20 Since the early 2000s, GSGBs have been faced with "a whole series of high-profile difficulties that have threatened the credibility of key sporting bodies" (Henry and Lee, 2004: 26), so the close 
relationship between partners, events and organizational ethics had to be addressed in the election debates. Possibly the candidates' reluctance to engage in technical matters related to the operationalization of good governance principles (such as voting procedures) is an effect of media tactics and politicization of election campaigns. But one can also suspect that great changes were out of reach because the challengers did not take advantage of the organizational culture of FIA. Pointing out shortcomings in FIA's governance practices in the election debates did not earn the challengers more votes. The majority of members were seemingly more concerned with maintaining the legacy from Mosley (when Todt succeeded him in 2009) and Todt (after his re-election in 2013) than reforming the organization in accordance with good governance principles elsewhere in the world of GSGBs.

\section{Conclusion}

In this article, the 2009 and 2013 election campaigns for the Presidency of the FIA have been analysed through QDA as a means to uncover how the organization has progressed with regard to good governance. Todt, the victorious candidate in 2009 and 2013, appeared to focus more on a stakeholder-effective FIA than on reforming the organization in accordance with established good governance principles. But when Vatanen based his campaign on the need for restructuring FIA, Todt had to clarify his own views on good governance. However, when Ward subsequently proposed in 2013 an even more radical reform, Todt went into defence mode and referred to the work done by Statutes Review Commission since he first was elected FIA President. At the same time, the extensive and liberal use of concepts related to good governance by Ward and Vatanen may paradoxically have reduced the credibility of their campaigns and their support from FIA members and the public. Vatanen, especially, tends to use "transparency" as an all-embracing term for ethically solid practice in governance.

These disagreements demonstrate that the challengers' aim to secure credibility by raising the issues of good governance did not pay off. A plausible hypothesis, which could be the basis for further research, is that the majority of FIA members who had a vote in the elections, valued the winning candidate's capacity to manage global motorsport series higher than a FIA president who complied with the good governance principles of comparable institutions like the IOC or FIFA. That is not to say that, if all the suggestions made by Vatanen and Ward had been acted upon, they would have reshaped the FIA into an organization in complete accord with for example the G20/ OECD principles of good governance. Ideas related to "transparency", "accountability" and "democratic representation" are by themselves no magic fix, since FIA's challenges-as demonstrated in this article-are historically and culturally founded. Moreover, the challengers failed to spell out in detail what their notion of good governance consisted of, which may be at least part of the reason why they did not gain credibility by raising them. As these issues are nevertheless likely to be addressed in the next FIA presidential election, which takes place in the autumn of 2017, a potential research topic for the future is therefore to explore specifically the position of member clubs and their views on these issues.

\section{Notes}

1 These numbers are gathered from "President's speech for the General Assembly 2015”, 4 December 2015. Retrieved 12 June 2016, from http://www.fia.com/news/ president's-speech-general-assembly-2015

2 Cited from "Jean-Marie Balestre est mort", Le Figaro, 21 July 2008. Retrieved 26 August 2016, from: http://www.lefigaro.fr/formule1/2008/03/28/02008-20080328 ARTSPO00507-jean-marie-balestre-est-mort.php.
3 FIA web page. Retrieved 22 August 2016, from: http://www.fia.com/about-fia/fiastatutes-and-internal-regulations.

4 "Bouman's guide to the FIA presidential elections", motorsport.com, 25 July 2009. Retrieved 22 August 2016, from: http://www.motorsport.com/general/news/boumans-guide-to-fia-presidential-elections/.

5 "Transparency to FIA". Campaign statement by Ari Vatanen (28 July 2009). Retrieved 21 August 2016, from: http://www.arivatanenrally.com/en/ari-vatanen/aristhoughts/transparency-to-fia.html.

6 "FIA body scolds Vatanen after Todt jibes", flagworld, 22 July. Retrieved August 22 2016, from https://www.flagworld.com/news/2009/07/22/fia-body-scolds-vatanenafter-todt-jibes/.

7 "Jean Todt reveals election manifesto for FIA presidency", Guardian, 6 August 2009. Retrieved 22 August 2016, from: https://www.theguardian.com/sport/2009/aug/06/ jean-todt-fia-presidency-election-manifesto.

8 "Bouman's guide to the FIA presidential elections", motorsport.com, 25 July 2009. Retrieved 22 August 2016, from: http://www.motorsport.com/general/news/boumans-guide-to-fia-presidential-elections/.

9 “Todt lauds 'professionalism' over 'personal attacks'”, crash.net, 14 October. Retrieved 22 August 2016, from: http://www.crash.net/f1/news/153478/1/todt-laudsprofessionalism-over-personal-attacks.html.

10 As FIA has 132 members this needs an explanation. Each of the 132 countries where the FIA is represented has a maximum two votes, one for mobility and one for sport. In countries where there is one club covering mobility and sport, that club will have two votes. Countries which have only either sport or mobility competence will have one vote. Hence, the total number of votes may surpass the total number of members.

11 Retrieved 1 July, 2015, from: http://wardandteam2013.com.

12 Retrieved 21 August, 2016, from: http://www.jeantodtandteam2013.com/the-roadforward/.

13 Retrieved 21 August 2016, from: http://www.jeantodtandteam2013.com/wp-content/ uploads/2013/10/ENG-Progress-Report.pdf.

14 Retrieved 21 August 2016, from: http://www.jeantodtandteam2013.com/4-years-ofchange/.

15 Retrieved 21 August 2016, from: http://www.jeantodtandteam2013.com/4-years-ofchange/.

16 "Vatanen promises FIA code of ethics if elected", efans.com, 17 October 2009. Retrieved 28 August 2016, from: http://www.efans.com/News/ViewNews.aspx? newsId $=2921$.

17 Retrieved 1 July 2015, from: http://wardandteam2013.com.

18 Retrieved 21 August 2016, from: http://www.jeantodtandteam2013.com/4-years-ofchange/.

19 Retrieved 1 July 2015, from: http://wardandteam2013.com.

20 "President Bach calls on National Olympic Committees to Safeguard Credibility of Sport”, olympic.org, 29 October 2015. Retrieved 21 February 2017, from https://www. olympic.org/news/president-bach-calls-on-national-olympic-committees-to-safe guard-credibility-of-sport.

\section{References}

Altheide D (1996) Qualitative Media Analysis. Sage: Newbury Park, CA.

Altheide D, Coyle M, DeVriese K, Schneider C (2008) Emergent qualitative document analysis In: Hesse-Biber SN and Leavy P (eds). Handbook of Emergent Methods. Guilford Press: New York, pp 127-155.

Atkinson P, Coffey A (1997) Analysing documentary realities In: Silverman D (ed) Qualitative Research Theory Method and Practice. Sage: London, pp 45-62.

Beer M (2009) 'FIA Foundation head defends Todt role'. Autosport, October 15, http://www.autosport.com/news/report.php/id/79451, accessed 22 August 2016.

Blitz R and Allen J (2009) 'Formula One puts leadership to vote', Financial Times, 23 October,https://www.ft.com/content/9240955e-bf3a-11de-a696-00144feab 49a, accessed 22 August 2016.

Bohlander GW and Schnell S (2010) Managing Human Resources. South-Western Cengage Learning: Mason, $\mathrm{OH}$.

Bowen GA (2009) Document analysis as a qualitative research method. Qualitative Research Journal; 9 (2): 27-40.

Brown D and Moore M (2001) Accountability, Strategy, and International Nongovernmental Organizations. Harvard University Press: Cambridge, MA.

Cary T (2009a) Ari Vatanen says he would bring change if elected FIA president. Telegraph 11 July, http://www.telegraph.co.uk/sport/motorsport/5804844/AriVatanen-says-he-would-bring-change-if-elected-FIA-president.html, 21 August 2016.

Cary T (2009b) Jean Todt reaches for the moral high ground in race for FIA presidency. Telegraph 22 July, http://www.telegraph.co.uk/sport/motorsport/ formulaone/f1news/5888389/Jean-Todt-reaches-for-the-moral-high-ground-inrace-for-FIA-presidency.html, accessed 21 August 2016.

Cary T (2009c) FIA presidency battle erupts into new row as leaked emails show support for Jean Todt. Telegraph 15 October, http://www.telegraph.co.uk/sport/ motorsport/formulaone/6328903/FIA-presidency-battle-erupts-into-new-rowas-leaked-emails-show-support-for-Jean-Todt.html, accessed 21 August 2016.

Cary T (2013a) Jean Todt's rival David Ward goes on attack in FIA presidential race. Telegraph 9 September, http://www.telegraph.co.uk/sport/motorsport/ 
formulaone/10297421/Jean-Todts-rival-David-Ward-goes-on-attack-in-FIApresidential-race.html, accessed 21 August 2016.

Cary T (2013b) Jean Todt takes a swipe at defeated rival David Ward after being elected as FIA president for second term. Telegraph 10 December, http://www. telegraph.co.uk/sport/motorsport/formulaone/10500600/Jean-Todt-takes-aswipe-at-defeated-rival-David-Ward-after-being-elected-as-FIA-president-forsecond-term.html, accessed 21 August 2016.

Clark T (2010) On "being researched": Why do people engage with qualitative research? Qualitative Research; 10 (4): 399-419.

Colucci M and Geeraert A (2013) The 'Social Dialogue' in professional European football. AGGIS report series/PlaytheGame.org, http://www.playthegame.org/ fileadmin/documents/AGGIS_article_-_social_dialogue_in_european_profes sional_football.pdf, accessed 17 January 2017.

Cooper A (2013a) David Ward launches campaign for top FIA job. Autoweek 5 September, http://autoweek.com/article/formula-one/david-ward-launches-cam paign-top-fia-job, accessed 21 August 2016

Cooper A (2013b) Ward still pushing for electoral reform, https://adamcooperf1. com/2013/11/08/ward-still-pushing-for-fia-electoral-reform/, accessed 21 August 2016.

Cooper A (2013c) David Ward drops out of FIA presidential race; Jean Todt now unopposed. Autoweek November 13, http://autoweek.com/article/formula-one/ david-ward-drops-out-fia-presidential-race-jean-todt-now-unopposed, accessed 21 August 2016

Cotton M (1991) Where next Mr President? Motor Sport Magazine November, http://www.motorsportmagazine.com/archive/article/november-1991/31/inter view, accessed 21 August 2016.

Du Plessis TC (2005) A Theoretical Framework of Corporate Online Communication: A Marketing Public Relations (MPR) Perspective. Ph.D. thesis, University of South Africa.

Economist. (2011) The business of Formula 1: A motor-racing Machiavelli. 16 October, http://www.economist.com/blogs/gametheory/2011/10/business-for mula-one, accessed 21 August 2016.

EJC (European Journalism Centre). (2013) Transparent and accurate public communication in sports In: Alm J (ed) Action for Good Governance in International Sports Organisations. Play the Game/Danish Institute for Sport Studies: Copenhagen, UK, pp 104-127.

Geeraert A (2013) The governance agenda and its relevance for sport: introducing the four dimensions of the AGGIS sports governance observer In: Alm J (ed). Action for Good Governance in International Sports Organisations. Play the Game/Danish Institute for Sport Studies: Copenhagen, UK, pp 9-21.

Geeraert A, Alm J, Groll M (2013) Good governance in international NonGovernmental sports organisations: An empirical study on accountability, participation and executive body members in sport governing bodies In: Alm J (ed). Action for Good Governance in International Sports Organisations. Play the Game/Danish Institute for Sport Studies: Copenhagen, UK, pp 190-218.

Gibson O (2009) Ari Vatanen drops legal challenge to FIA presidential voting. Guardian October 20 https://www.theguardian.com/sport/2009/oct/20/ari-vata nen-fia-presidency-mosley, accessed 26 August.

Hajer MA (1995) The politics of environmental discourse. Ecological modernization and the policy process. Clarendon: Oxford.

Hamilton M (2009) Dirty politics? Bring in the cleaner... Motor Sport Magazine September, $50-54$.

Hassan D and Mitra S (eds) (2016) The Olympic Games: Meeting new challenges. Routledge: London.

Henry I, Lee PC (2004) Governance and ethics in sport In: Chadwick S and Beech J (eds). The Business of Sport Management. Pearson Education: Harlow, UK, pp $25-42$.

Herbig P and Milewicz J (1995) To be or not to be...credible that is: a model of reputation and credibility among competing firms. Marketing Intelligence \& Planning; 13 (6): 24-33.

Holzner B and Holzner L (2006) Transparency in Global Change-The Vanguard of the Open Society. University of Pittsburgh Press: Pittsburgh, PA.

Hood C (2006) Transparency in historical perspective In: Hood C and Held D (eds). Transparency. The Key to Better Governance? Oxford University Press: Oxford, pp 3-23.

Houlihan B (2004) Sports globalisation, the state and the problem of governance In: Slack T (ed). The Commercialisation of Sport. Routledge: London, pp 52-75.

House RJ and Mitchell TR (1974) Path-goal theory of leadership. Contemporary Business; 3, 81-98.

Hutton R (2004) FIA Centenary Book. FIA: Paris, France.

Kohlbacher F (2005) The Use of Qualitative Content Analysis in Case Study Research. Forum Qualitative Sozialforschung / Forum: Qualitative Social Research, 7(1), Art. 21, http://nbn-resolving.de/urn:nbn:de:0114-fqs0601211.

Lardo A, Trequattrini R, Lombardi R and Russo G (2016) Co-opetition models for governing professional football. Journal of Innovation and Entrepreneurship; 5 (1): 1 .
Leroy H, Palanski M and Simons T (2012) Authentic leadership and behavioral integrity as drivers of follower commitment and performance. Journal of Business Ethics; 107 (3): 255-264.

Lovell T (2004) Bernie's game. Inside the Formula 1 world of Bernie Ecclestone. Metro books: London.

MacAloona JJ (2011) Scandal and governance: Inside and outside the IOC 2000 Commission. Sport in Society: Cultures, Commerce, Media, Politics; 14 (3): 292-308.

McEvoy J (2013) Ward slapped down by FIA over allegations that Todt abused power in re-election race. The Daily Mail 23 October, http://www.dailymail.co. uk/sport/formulaone/article-2473433/David-Ward-slapped-FIA-allegationsJean-Todt-abused-power.html, accessed 22 August 2016.

Minikin B (2015) Legitimacy and democracy: implications for governance in sport. Sport, Business and Management: An International Journal; 5 (5): 435-450.

Mittag J, Putzmann N (2013) Reassessing the democracy debate in sport alternatives to the one-association-onevote-principle? In: Alm J (ed). Action for Good Governance in International Sports Organisations. Play the Game/ Danish Institute for Sport Studies: Copenhagen, UK, pp 83-97.

Mosley M (2001) Keynote speech. Printed in The Rules of the Game, conference report, pp 22-25, https://www.fia.com/sites/default/files/basicpage/file/govern ance_sport.pdf, accessed 4 September 2012.

Mosley M (2015) The Autobiography: Formula One and Beyond. Simon and Schuster: London.

Neuman WL (1997) Social research methods, qualitative and quantitative approaches, Third Edition, Allyn and Bacon: Boston, MA

Noble J and Elizalde P (2009) Vatanen unhappy at Mosley stance. Autosport 17 July, http://www.autosport.com/news/report.php/id/77019, accessed 22 August 2016.

Osborne P (2013) FIA to revise rules ahead of the Presidential election. Inside the games 21 October, http://www.insidethegames.biz/articles/1016602/fia-torevise-rules-ahead-of-presidential-election, accessed 22 August 2016.

Panzariu O (2009a) FIA Slams Vatanen for Todt Attack. Autoevolution 22 July, http://www.autoevolution.com/news/fia-slams-vatanen-for-todt-attack-9024. html, accessed 22 August 2016.

Panzariu O (2009b) FIA in Breach of Neutrality after Leaked Emails. Autoevolution 15 October, http://www.autoevolution.com/news/fia-in-breach-of-neutralityafter-leaked-emails-12046.html, accessed 22 August 2016.

Potter WJ (2009) An Analysis of Thinking and Research About Qualitative Methods. Routledge: New York/London.

Rowland J (2013) Analysis of FIA governance using the Basic Indicators for Better Governance in Sport assessment tool. I Trust Sport, http://www.itrustsport.com/ assets/misc/I_Trust_Sport_analysis_of_FIA_governance_using_BIBGIS_tool. pdf, accessed 1 August 2016.

Saward J (1993) Why has FISA been abolished? grandprix.com 1 September, http:// www.grandprix.com/ft/ft00162.html, accessed 21 August 2016.

Saward J (2008) The World Motor Sport Council. What is it? Motorsport Magazine March, http://www.motorsportmagazine.com/archive/article/march-2008/66/ world-motor-sport-council-what-it, accessed 12 August 2016.

Simons TL (2002) Behavioral integrity: The perceived alignment between managers' words and deeds as a research focus. Organization Science; 13 (1): $18-35$.

Skid SJ (2009) Vatanen releases his manifesto, Todt flexes political muscle. formula1blog.com 21 August, http://www.formula1blog.com/21/vatanenreleases-his-manifesto-f1-formula1-fia-vatanen/comment-page-1/, accessed 23 August 2016.

Slack T and Parent MM (2006) Understanding Sport Organization. The Application of Organization Theory, Second Edition, Human Kinetics: Champaign, IL.

Tomlinson A (2014) FIFA: The men, the myths, and the money. Routledge: London. Tracy SJ (2010) Qualitative quality: Eight "big-tent" criteria for excellent qualitative research. Qualitative Inquiry; 16 (10): 837-851.

Young O (1994) International Governance: Protecting the Environment in a Stateless Society. Cornell University Press: Ithaca, NY.

Yukl GA (1998) Leadership in Organizations, Fourth Edition, Prentice-Hall: Englewood Cliffs, NJ.

Vatanen A (2009) Presidential Manifesto. 20 August, http://www.autoevolution. $\mathrm{com} / \mathrm{pdf} /$ news_attachements/ari-vatanen-presents-election-agenda-to-the-fia10123.pdf, accessed 21 September 2016.

Weber M (1968) Economy and Society: an outline of interpretive sociology. Bedminster Press [1922]: New York.

Wesley JJ (2014) The qualitative analysis of political documents In: Kaal B, Maks I and Elfrinkhof A (eds). From Text to Political Positions: Text Analysis Across Disciplines. John Benjamins Publishing Company: Amsterdam, UK, pp 135-160.

Woods N (1999) Good governance in international organisations. Global Governance; 5 (1): 39-61. 


\section{Data availability}

All data generated or analysed during this study are included in this published article.

\section{Acknowledgements}

Thanks to Andrew Milner for relevant input and editorial work.

\section{Additional information}

Competing interests: The author declares that there are no competing financial interests.

Reprints and permission information is available at http://www.palgrave-journals.com/ pal/authors/rights_and_permissions.html
How to cite this article: Næss HE (2017) A race towards credibility: the 2009 and 2013 presidential election campaigns at the Fédération Internationale de l'Automobile (FIA). Palgrave Communications. 3:17024 doi: 10.1057/palcomms.2017.24.

(c) (i) This work is licensed under a Creative Commons Attribution 4.0 cc. International License. The images or other third party material in this article are included in the article's Creative Commons license, unless indicated otherwise in the credit line; if the material is not included under the Creative Commons license, users will need to obtain permission from the license holder to reproduce the material. To view a copy of this license, visit http://creativecommons.org/licenses/by/4.0/ 